\title{
Recent changes in the crater of steomboli
}

\section{Tempest Anderson M.D., D.Sc.}

To cite this article: Tempest Anderson M.D., D.Sc. (1905) Recent changes in the crater of steomboli , Scottish Geographical Magazine, 21:7, 345-347, DOI: 10.1080/00369220508733583

To link to this article: http://dx.doi.org/10.1080/00369220508733583

册 Published online: 27 Feb 2008.

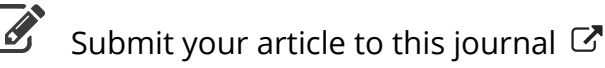

III Article views: 5

Q View related articles ๘ 


\section{THE SCOTTISH \\ GEOGR A P H I C A L \\ MA GAZINE.}

\section{RECENT CHANGES IN THE CRATER OF STROMBOLI. ${ }^{1}$ \\ By Tempest Anderson, M.D., D.Sc.}

(Tith Illustrations.)

STromboli is the most easterly and northerly of the Lipari Islands. It is situated north of Sicily, close to the track of steamers plying between Naples and the Straits of Messina, and is thus an object familiar to passengers to or from Egypt or the East, though comparatively few have landed on its shores. Its almost constant eruptions have gained it the name of the lighthouse of the Mediterranean. It is almost circular, as its old name Strongyle indicates, and rises as an irregular cone out of deep water. On the NW. side are the crater, and the Sciara or steep slope down which the ejecta roll into the sea.

The summit of the mountain, which is about 3000 feet high, consists of a crescentic ridge, the Serra di Vancori, open towards the north. It forms part of an old crater ring, and thus presents points of similarity to Somma. Inside the crescentic ridge, and in places joined to it by - irregular crests of rock, but mainly separated from it by a valley, " $\mathbf{A}$ Fossieiedda," similar to the Atrio del Cavallo of Vesuvius, is another crescentic ridge, connected with the two extremities of which, and immediately overlooking the sides of the crater, are two conspicuous pointed rocks, the Torrelle, which partly obstruct the view of the crater when viewed from the cliffs overlooking the Sciara on its NE. and SW. respectively. These Torrelle, being practically unaltered by ordinary eruptions, present good points of comparison for estimating the changes that take place. Between the two Torrelle, in the midst of a sort of

1 Abridged from a Paper in the Geographical Journal for Feb. 1905. VOL. XXI. 
amphitheatre formed by them and the crescentic ridge last mentioned, are the crater and its appurtenances, the "Apparato Eruttivo " of Italian observers. This amphitheatre is open to the NIV., and from its open side beyond the craters the steep slope of the Sciara extends down into the sea. This slope is bounded on each side by two steep cliffs, Filo di Sciara and Filo di Barcuna, which are formed, like the Sciara itself, of lava-streams, agglomerates, and dykes; in fact, of almost every kind of compact volcanic material, chiefly of basic composition.

This Sciara, as is well known, is one of the most peculiar features of this volcano. It extends at an angle of about $35^{\circ}$, which is the "angle of repose" for the kind of material of which it is composed, down into the deep water of the Mediterranean; and though the volcano has certainly been in almost constant eruption during the whole of the historic period; and probably much longer, it has never been able to build up a talus sufficient to rise to the level of the sea, much less to that of the lip of the crater, about which, according to the analogy of other volcanoes, it might have been expected to have built up a cone on this side comparable to the portion on the south described above. The illustration, "The Sciara from the NE.," from a photograph taken by the author in 1888 from the ridge overlooking the $\mathrm{NE}$. side of the Sciara, and consequently looking SW., shows the Sciara extending down to the right of the picture with the Filo di Barcuna behind it. The pointed rock to the left of the picture is the eastern Torrella, with a gap to the left of it through which the ejecta are thrown during the larger eruptions, and roll on to the steep slopes in front and down the Sciara into the sea. The western Torrella is just visible in the distance beyond the eastern Torrella. The crater situated between the two was in 1888 a large pit obviously formed by severe explosions. It contained two small secondary cones. One, towards its western part, and close to the edge of the Sciara, was that from which the explosive eruptions took place several times an hour; the other, towards the eastern part, emitted only smoke.

In 1904, when the author took comparison photographs from nearly the same spot, this large crater was almost entirely filled up, and the slope of the Sciara was continued upwards, so that the cone of ejecta overtopped and was visible behind the eastern Torrella. The activity in this eastern part of the crater still maintained the same quiet character as in 1888. The whole area constantly emitted vapour; there was more than one bocca visible, but they were quite small, and only gave very feeble explosions, and these with a rhythm quite independent of those at : the western part of the crater.

The illustration, "Stromboli. An Explosion. Early Stage," taken by the author on April 20,1904, from a point to the west of the crater, and consequently in almost exactly an opposite direction to that showing the Sciara from the NE., shows the condition of the western part of the crater sixteen years later. The conspicuous rock to the right of the plate is the western Torrella, behind which, in 1888, was the great crater above referred to. The bocca to the left, from which the explosion is taking place, is shown in some of the earlier photographs as situated on the edge of the larger crater at its junction with the Sciara. The great 


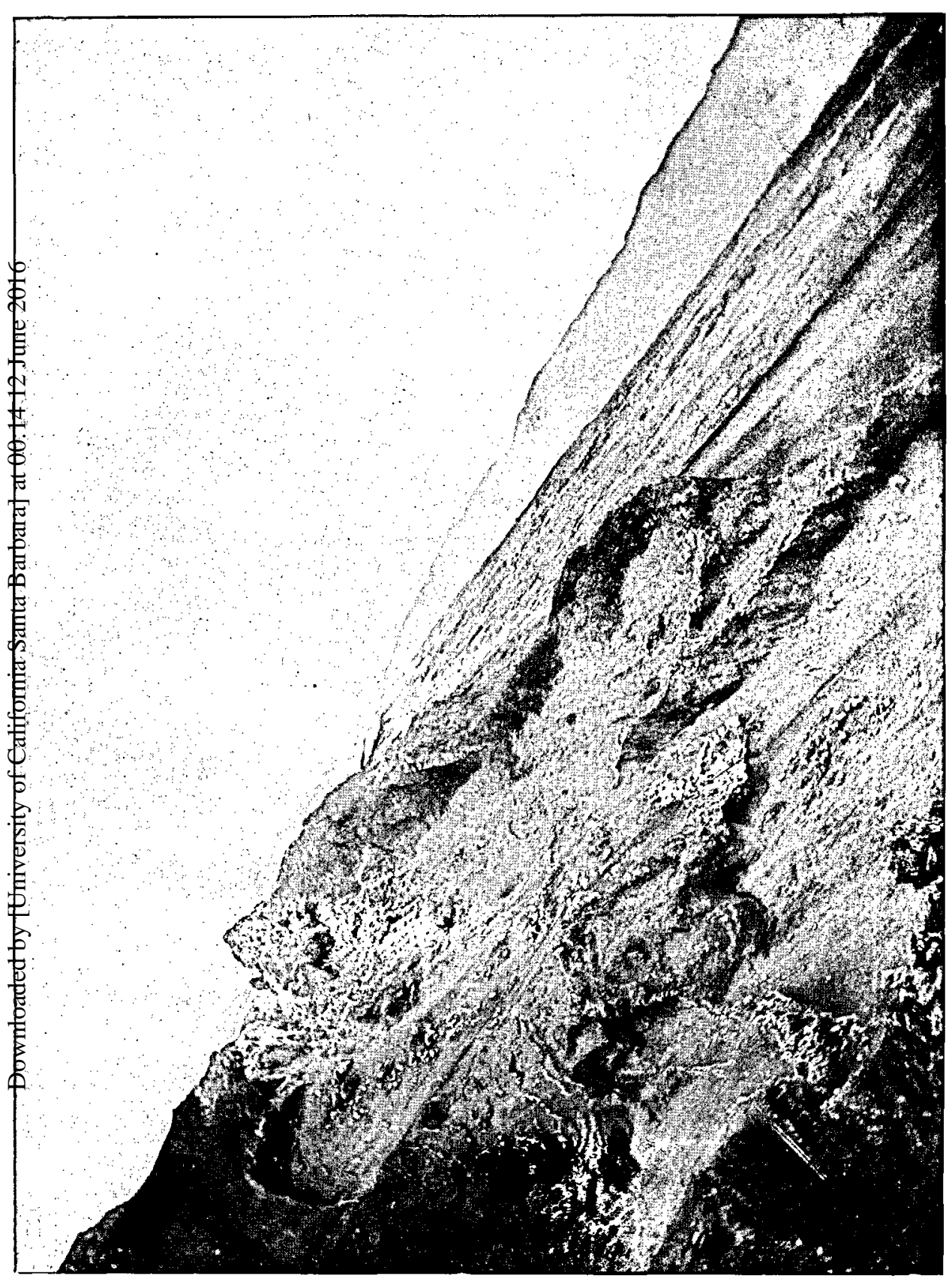

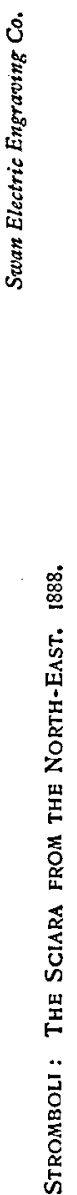

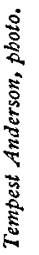


crater is now seen to be filled up by ejecta which prolong the slope of the Sciara upwards over what was previously its site, while the bocca itself remains in all probability really in its former position, though apparently on the slope of the Sciara instead of on its edge.

It will be interesting to future visitors to see whether the volcano will continue to prolong the slope of the Sciara much further upwards, or whether a paroxysmal explosion will occur which will clear the great crater again.

\section{IN THE LIPARI ISLANDS. ${ }^{1}$}

\section{By GEORGE YELD, Editor of the Alpine Journal.}

ON April 14, 1904, Dr. Tempest Anderson and I, in company with Dr. Cool and Herr Philip, arrived at Milazzo, the ancient Mylæe, a little town at the southern end of the promontory of the same name in the NE. of Sicily. We drove to the. Albergo Genova, where we afterwards spent the night. Half-a-dozen street arabs pertinaciously thrust their services upon us as luggage-carriers, and amused us much at small expense. The same evening we visited the castle on the hill to the north. On the western side of the promontory, much of which was covered with olive yards, was a charming little bay; in one or two places where a gap in the cliffs was less steep a stream of olives, so to speak, flowed down to the shore. The smoke of Stromboli was visible over not quite the highest point of the olive yards. But the great feature of the view was Etna-vast, even overwhelming in size. The parasitic cones on the W., or probably SW., ridge of it to Anderson's educated eye spoke volumes, but to me the glimpses of torrent beds and little towns perched on steep hills were more eloquent. The sunset was glorious.

The next morning on the most peaceful of seas and an ancient mail-boat we crossed the Lipari. On the east side of the Milazzo promontory the olives came down to the very edge of the shore. We noticed a line of caves just above the present water-line-perhaps six feet above itwhich would mean, so Anderson explained to me, that the land had risen -in the same way that at Pozzuoli the land has gone down and risen again in historic times. Etna was still the great feature of our view.

At Lipari we put up at the Hotel Traina, where Signor Traina did his best for us. The house is, like the other houses in Lipari, flat-roofed, and by climbing a ladder it was possible to reach a higher roof, from which one could see the little bay. The accommodation was, of course, somewhat primitive, but we were fairly comfortable. We spent the rest of the day in a visit to San Calogero and its hot springs on the west side of the island, the town of Lipari being on the east coast.

On the way back we left the main track, and turning to the right after covering some little distance gained a most lovely view of the wastes of Vulcano. In the narrowest part of the path I met a small cow in charge of a little child, who endeavoured to secure the mastery by means of a rope, but the cow acted as leading guide; the child had

1 Reprinted from the Alpine Journal for May 1905. 